\title{
CD83 Antigen
}

National Cancer Institute

\section{Source}

National Cancer Institute. CD83 Antigen. NCI Thesaurus. Code C84313.

CD83 antigen (205 aa, $23 \mathrm{kDa}$ ) is encoded by the human CD83 gene. This protein may play a role in antigen presentation. 